\title{
Expansion and homogeneity of the vertical distribution of zooplankton in a very deep mixed layer
}

\author{
Viviana Farstey ${ }^{1, *}$, Boaz Lazar $^{2}$, Amatzia Genin $^{3}$ \\ ${ }^{1}$ The Interuniversity Institute for Marine Sciences, H. Steinitz Marine Biology Laboratory, POB 469, Eilat 88103, Israel \\ ${ }^{2}$ The Institute of Earth Sciences and Moshe Shilo Center for Biogeochemistry, The Hebrew University, Jerusalem 91904, Israel \\ ${ }^{3}$ The Interuniversity Institute for Marine Sciences and Department of Evolution, Systematics and Ecology, The Hebrew \\ University, POB 469, Eilat 88103, Israel
}

\begin{abstract}
During stratification over $70 \%$ of the zooplankton $>100 \mu \mathrm{m}$ in the Gulf of Aqaba (Eilat), Red Sea, resided in the upper $100 \mathrm{~m}$. In the course of winter mixing, the vertical pattern became more homogeneous, reaching an almost complete uniformity when the vertical mixing exceeded $500 \mathrm{~m}$ depth. The zooplankton expanded its vertical distribution throughout the mixed layer. However, full homogeneity, such as would be expected for a passive tracer and observed for phytoplankton, occurred for zooplankton only in the upper section of the mixed layer. Homogeneity occurred for zooplankton passing through $750 \mu \mathrm{m}$ mesh but not for larger crustaceans. The copepod Pleuromamma indica retained its diel vertical migration regardless of mixing but expanded its nocturnal range under mixing conditions. The observed homogeneity of zooplankton could have been reached either by passive entrainment with the mixing water or by isotropic swimming of the animals, or both. The ecological implications of the expansion of zooplankton distribution for predator-prey relationships and particle fluxes are discussed.
\end{abstract}

KEY WORDS: Plankton · Vertical mixing $\cdot$ Red Sea

\section{INTRODUCTION}

Previous studies addressing the relationship between the vertical distribution of zooplankton and water column stratification focused on small-scale patterns within the photic layer ( $\leq 100 \mathrm{~m}$ depth) (Buckley \& Lough 1987, Checkley et al. 1992, Incze et al. 1996), indicating a more even zooplankton distribution in well-mixed than in stratified columns. For example, Checkley et al. (1992) compared the vertical distribution of zooplankton $>100 \mu \mathrm{m}$ in 2 different neritic sites, a tidally mixed column near Japan and a stratified column in the Gulf of Mexico. While a roughly uniform vertical distribution was found in the well-mixed site, discrete vertical patterns occurred in the stratified site. A similar homogeneity extending to $100 \mathrm{~m}$ in a well

*E-mail: viviana@vms.huji.ac.il mixed water column and a segregated vertical distribution in stratified water columns were reported for Calanus finmarchicus and C. helgolandicus in the Celtic Sea (Williams 1985).

Deep winter mixing reaching aphotic layers occurs in the Sargasso Sea (Menzel \& Ryther 1960, Longhurst 1998), in high latitudes (Longhurst 1998) and in warmcore eddies (Tranter et al. 1980, Bradford et al. 1982, Zohary et al. 1998). The consequent changes in the vertical distribution of phytoplankton, but not zooplankton, under such mixing conditions are well documented (Sverdrup 1953, Bradford et al. 1982, Lindell \& Post 1995, Zohary et al. 1998).

Unusually deep mixing occurs every winter in the northern part of the Gulf of Aqaba (Eilat) in the Red Sea (Genin et al. 1995). Seasonal conditions change; from stratification with a very shallow (0 to $30 \mathrm{~m}$ ) windmixed layer during the warm months (May to September) to deep convective mixing, extending several 
hundred meters below the surface during the winter (Reiss \& Hottinger 1984, Wolf-Vecht et al. 1992, Genin et al. 1995). Reports from that region attributed the observed seasonality in the community structure of ultraphytoplankton (Lindell \& Post 1995), coccolithophores (Winter et al. 1979) and microplankton (Kimor \& Golandsky 1977) to water-column stability and the degree of mixing. For example, ultraphytoplankton, including Synechococcus and small eukaryotic cells, were uniformly distributed throughout a $600 \mathrm{~m}$ deep mixed layer during the cold winter of 1992/1993 (Lindell \& Post 1995), indicative of their passive entrainment by mixing. A similar homogeneous distribution in the mixed layer was reported for large $(>65 \mu \mathrm{m})$ diatoms and dinoflagellates during winter 1975 (Kimor \& Golandsky 1977) and for coccolithophores in February 1976 (Winter et al. 1979). Likewise, the extended distribution of typical Red Sea epipelagic oncaeid species down to $300 \mathrm{~m}$ depth in the Gulf during winter 1999 was also ascribed to the nearly homogeneous and well oxygenated water column (Böttger-Schnack et al. 2001). This study further explores the effect of the deep convective mixing in the Gulf of Aqaba (Eilat) on the vertical distribution of zooplankton and on the vertical migration of the calanoid copepod Pleuromamma indica Wolfenden, 1905.

\section{MATERIALS AND METHODS}

The study was carried out at Stn A $\left(29^{\circ} 28^{\prime} \mathrm{N}\right.$, $\left.34^{\circ} 56^{\prime} \mathrm{E}\right)$, a 600 to $700 \mathrm{~m}$ deep site, $3 \mathrm{~km}$ off the $\mathrm{H}$. Steinitz Marine Biology Laboratory in the northern part of the Gulf of Aqaba (Eilat), Red Sea. Reiss \& Hottinger (1984), Wolf-Vecht et al. (1992) and Genin et al. (1995) described the climatic and oceanographic conditions at this site. The photic layer ( $1 \%$ light level) is around $100 \mathrm{~m}$.

This report is part of a 2 yr study (January 1991 through June 1993) of zooplankton dynamics at Stn A. Here we present the results of all our winter cruises, carried out when the vertical mixing surpassed $100 \mathrm{~m}$ (December 1991, January, February and December 1992, January and February 1993) and representative cruises from summer when the water column was stratified (August to September 1992, June 1993). Zooplankton samples were taken aboard the RV 'Jadran' using a WP2 net (HydroBios) of $57 \mathrm{~cm}$ mouth diameter, and $100 \mu \mathrm{m}$ mesh, with a pre-calibrated flow meter (TSK). The net was hauled vertically at approx. $0.8 \mathrm{~m}$ $\mathrm{s}^{-1}$ and choke-closed at the top of the sampled layer using a messenger. Samples were preserved upon retrieval in a $4 \%$ buffered formalin-sea water solution. Two sets of net hauls were performed on each cruise in 1991 and 1992, one around midday, the other around midnight. Each set consisted of 6 vertical hauls, each sampling a $100 \mathrm{~m}$ layer from $600 \mathrm{~m}$ to the surface. The average volume filtered per sample was $26 \pm 11 \mathrm{~m}^{3}$ ( $\mathrm{n}=102$ ). A full profile took 3 to $4 \mathrm{~h}$ to complete. For logistical reasons, only the midday tow was made in each of the 1993 cruises. The data presented here are based on a total of 15 vertical profiles (9 midday, 6 nighttime; Table 1).

Zooplankton samples were counted in the laboratory using a dissecting microscope. Sub-samples were taken using a Stempel pipette so that at least 400 specimens were counted per sample. In order to examine the effect of body size on the level of vertical homogeneity in 2 profiles (noon in February and September 1992), the samples were size-fractionated using a column of 100, 400, and $750 \mu \mathrm{m}$ mesh filters. The counted specimens were sorted into the following groups: large phytoplankton (dinoflagellates and diatoms), tintinnids, sarcodines, nauplii of copepods, copepods (copepodites and adults), molluscs, chaetognaths, and a combined category of all other specimens. Profiles having less than 1500 specimens per $1 \mathrm{~m}^{2}$ for a particular group were omitted from the analysis. In order to compare the distribution of the strong diel migrating copepod Pleuromamma indica between extreme conditions of stratification and deep mixing, all the copepodites and adults of this species sampled in the day and night profiles from 3 summer and 3 winter cruises from 1992 were counted.

Temperature and salinity profiles were measured on accompanying cruises using a STD (Applied Microsystems, STD-12) within $13 \mathrm{~d}$ prior to or after each zooplankton sampling. The stratification at the study site is determined mostly by temperature, with a negligible effect of salinity (Reiss \& Hottinger 1984, Genin et al. 1995). Hence, the bottom of the mixed layer was defined as the shallowest depth at which the tempera-

Table 1. Dates and times of zooplankton sampling and the corresponding mixed layer depth (MLD) at 'Stn A' in the Gulf of Aqaba (see 'Materials and methods' for the calculation of the MLD in the winter months)

\begin{tabular}{|c|c|c|c|}
\hline Zooplankton & Day & Night & MLD (m) \\
\hline 11-12 Dec 1991 & + & + & 146 \\
\hline 16-17 Jan 1992 & + & + & 316 \\
\hline 13-14 Feb 1992 & + & + & 510 \\
\hline 14-15 Jul 1992 & + & + & 12 \\
\hline 11-12 Aug 1992 & + & + & 24 \\
\hline $17-18$ Sep 1992 & + & + & $20^{\mathrm{a}}$ \\
\hline 9-10 Dec 1992 & + & + & 214 \\
\hline 6 Jan 1993 & + & & 309 \\
\hline 9 Feb & + & & 549 \\
\hline 23 Jun 1993 & + & & 17 \\
\hline
\end{tabular}



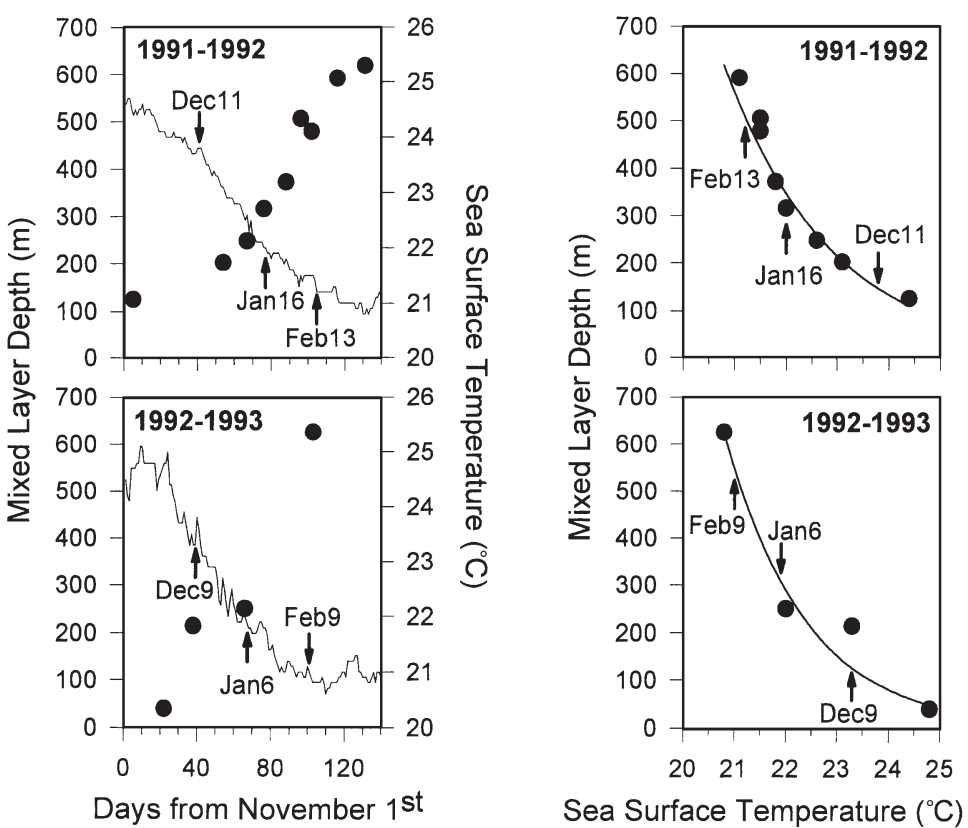

Sea Surface Temperature $\left({ }^{\circ} \mathrm{C}\right)$

Fig. 1. Left panels: Variations in the SST (line), measured daily from the pier of the marine underwater observatory, and MLD (closed circles), measured in Stn A, during the winter months of 1992 and 1993 (November to March). Right panels: MLD plotted against the corresponding SST. The exponential regression equations are $\mathrm{MLD}=13 \times 10^{6} \mathrm{e}^{-0.48 \mathrm{SST}}\left(\mathrm{R}^{2}=0.97, \mathrm{n}=8\right)$ for winter 1991/1992 and MLD $=38 \times 10^{7} \mathrm{e}^{-0.64 \mathrm{SST}}\left(\mathrm{R}^{2}=0.92, \mathrm{n}=4\right)$ for winter $1992 / 1993$. Arrows in both panels indicate the date of our plankton cruises

ture declined by at least $0.1^{\circ} \mathrm{C}$ (Simó \& Pedrós-Alió 1999). The mixed layer depth (MLD) was fairly constant during summer, never exceeding $30 \mathrm{~m}$; therefore, a separation of $13 \mathrm{~d}$ between the zooplankton and STD measurements in this season was not critical for the subject addressed in this work. However, an accurate determination of mixing depths at the time of zooplankton sampling was important in the winter. Sea surface temperature (SST) was measured daily from the pier of the Marine Underwater Observatory north to the Marine Biology Laboratory (Genin et al. 1995). The MLD and the daily change in the SST, measured between November and March in 1992 and 1993, are presented in Fig. 1. During these periods the MLD at Stn A increased continuously corresponding to the progressive decline in the SST measured from the pier (see Fig. 1, left panels). Note that the maximal MLD was at least $600 \mathrm{~m}$ in both March 1992 and February 1993. The MLD increased exponentially with the decrease in the SST: in winter 1991/1992, MLD $=13 \times$ $10^{6} \mathrm{e}^{-0.48 \times \text { SST }}, \mathrm{R}^{2}=0.97, \mathrm{n}=8$; and in winter 1992/1993, $\mathrm{MLD}=38 \times 10^{7} \mathrm{e}^{-0.64 \times \mathrm{SST}}, \mathrm{R}^{2}=0.92, \mathrm{n}=4$ (Fig. 1, right panels). For zooplankton samples taken within $1 \mathrm{~d}$ of direct STD measurement, the measured MLD value was used. Otherwise, the MLD was extrapolated based on the above exponential regression lines.
As mixing depths did not exceed $30 \mathrm{~m}$ during the summer (Genin et al. 1995, B. Lazar unpubl. data), all samples from June through September were pooled for the quantitative analyses into a single category, termed 'Summer'. All other samples were separated based on cruise dates into 3 monthly periods: December, January, and February, corresponding to intermediate (146 to $214 \mathrm{~m})$, deep (309 to $316 \mathrm{~m}$ ), and very-deep (510 to $549 \mathrm{~m}$ ) mixing, respectively (Table 1).

Vertical profiles of chlorophyll a ( $\mathrm{chl}$ a) were measured between the surface and 500 to $550 \mathrm{~m}$ on 10 February 1992, when the MLD was $478 \mathrm{~m}$, and on 11 August 1992, when the water column was stratified. Chlorophyll measurements were made using the standard technique of $24 \mathrm{~h}$ dark extraction in $90 \%$ acetone using water samples of $250 \mathrm{ml}$ collected with Niskin bottles and filtered on GF/F filters. The chlorophyll concentration in the extracted solution was read with a pre-calibrated Turner Design Model 10 Fluorometer.

The abundance of zooplankton was calculated in terms of both the density (no. $\mathrm{m}^{-3}$ ) and the proportion (\%) found in each $100 \mathrm{~m}$ layer. Two ratios were used to characterize the vertical homogeneity: $R_{1}$ - the abundance in the top $100 \mathrm{~m}$ divided by that in the 100 to $200 \mathrm{~m}$ layer; and $\mathrm{R}_{2}$ - the abundance in the 0 to $200 \mathrm{~m}$ divided by that in the 200 to $400 \mathrm{~m}$ layer. $\mathrm{R}_{1}$ and $\mathrm{R}_{2}$ were expected to be highest during the summer and lowest, near unity, after the vertical mixing had reached 200 and $400 \mathrm{~m}$, respectively. The effect of the period (4 'levels') on each of the ratios $\left(R_{1}\right.$ and $\left.R_{2}\right)$ was tested using 1-way ANOVA followed by Tukey's HSD post-hoc test (nonequal $\mathrm{N}$ ) after log transforming the ratios to comply with the requirement for homogeneity of variance $(p>$ 0.05, Cochran Test). Statistical tests were performed using Statistica (1999 Edition, StatSoft).

\section{RESULTS}

The depth of the mixed layer was shallower than $24 \mathrm{~m}$ in all summer cruises (June to September), around 150 to $200 \mathrm{~m}$ in December, ca. $300 \mathrm{~m}$ in January, and exceeded $500 \mathrm{~m}$ in February (Table 1).

Changes in the vertical distribution of zooplankton co-varied with changes in the mixed-layer depth (Fig. 2). Under stratified conditions in the summer, 60 to $90 \%$ of the zooplankton in the water column was found in the photic layer (upper $100 \mathrm{~m}$ ) with less than 


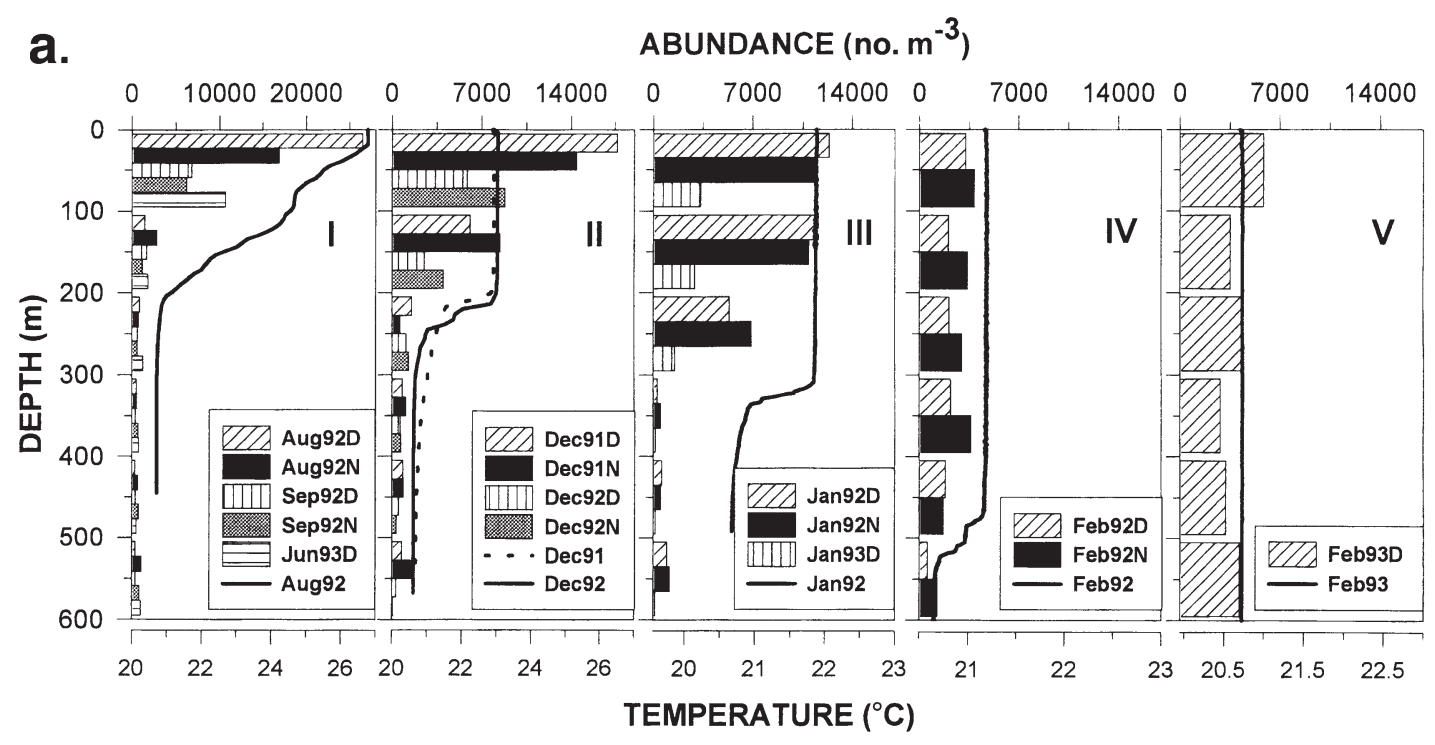

b. PERCENTAGE (\%)

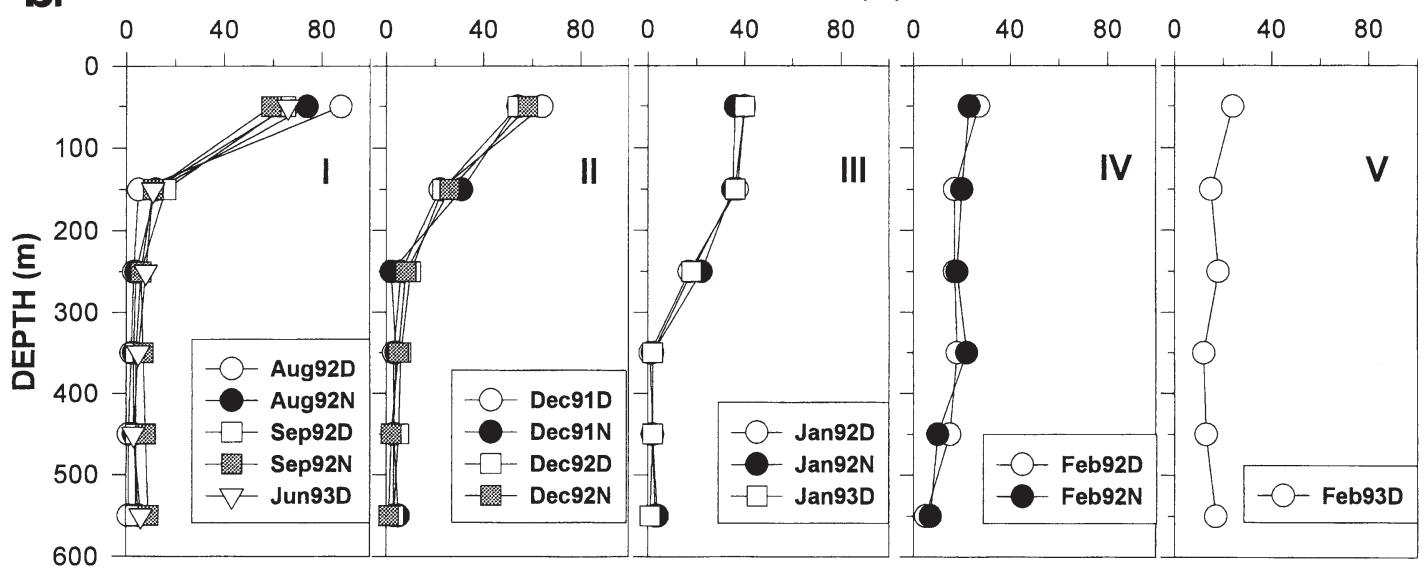

Fig. 2. Vertical profiles of total zooplankton and temperature in Summer (I), December (II), January (III) and February 1991 to 1993 (IV, V). (a) Zooplankton abundance (bars) and temperature (lines); (b) percentages of zooplankton in each layer of the total integrated over the $600 \mathrm{~m}$ water column during the same periods as in a. The letters $\mathrm{D}$ and $\mathrm{N}$ to the right of the date in the legends indicate day or night profile, respectively. Note the different ranges and scales used for temperature in the different plots

$16 \%$ in the layer just below it (100 to $200 \mathrm{~m}$ ). In December, when vertical mixing reached ca. 150 to $200 \mathrm{~m}$, only 54 to $64 \%$ of the zooplankton resided in the upper $100 \mathrm{~m}$, with 22 to $31 \%$ in the 100 to $200 \mathrm{~m}$ layer. When mixing exceeded $300 \mathrm{~m}$, over $90 \%$ of the zooplankton in the water column was evenly distributed within the mixed layer. A nearly uniform distribution of zooplankton was observed throughout the upper 400 to $500 \mathrm{~m}$ in February. This pattern was evident in both day and night and in different years (Fig. 2b) despite substantial inter-annual differences in the overall abundance of the zooplankton (Fig. 2a).

Values for $R_{1}$ and $R_{2}$ spanned an order of magnitude throughout the year, ranging from 18 to 19 in summer to nearly 1.0 in winter (Fig. 3). $\mathrm{R}_{1}$ sharply declined in
December, when the vertical mixing of the water reached 146 to $214 \mathrm{~m}$, reaching unity in January after mixing had exceeded $200 \mathrm{~m}$. $\mathrm{R}_{2}$ declined more gradually, approaching unity only in February, after the water-column mixing had surpassed $400 \mathrm{~m}$ depth (Fig. 3). The effect of period on each of the ratios $\mathrm{R}_{1}$ and $\mathrm{R}_{2}$ was highly significant (ANOVA, $\mathrm{p}<0.001$; Table 2 ). Post-hoc tests (Tukey HSD) indicated significant differences $(p<0.01)$ between $R_{1}$ during the summer and $R_{1}$ during each of the 3 winter months, with non-significant differences $(p>0.1)$ between winter months. Significant differences in $\mathrm{R}_{2}$ were found only between February and each of the 3 other periods (Table 2).

Nauplii, copepods, chaetognaths, molluscs, tintinnids, sarcodines, and phytoplankton, passing through 


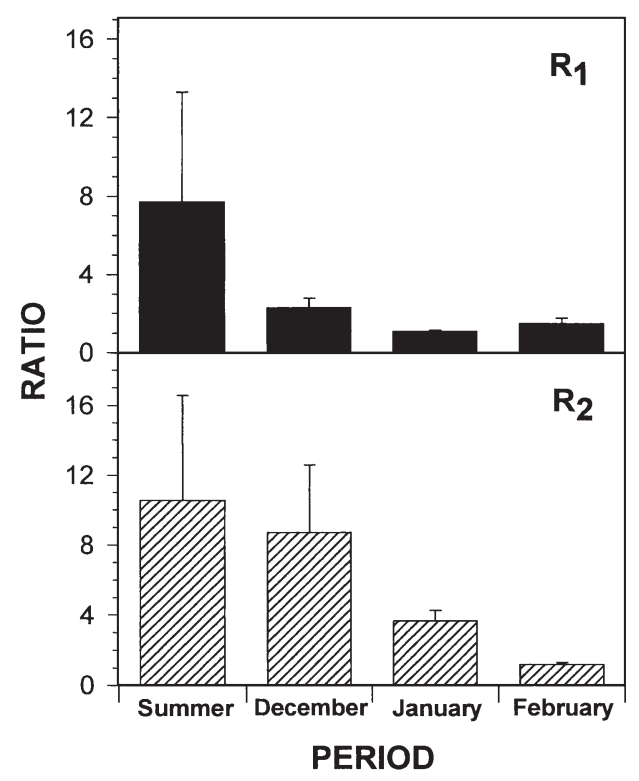

Fig. 3. Average $(+\mathrm{SD})$ values of the ratio of zooplankton abundance between the $0-100$, and $100-200 \mathrm{~m}$ layers $\left(R_{1}\right.$, upper part) and between the $0-200$, and $200-400$ m layers $\left(R_{2}\right.$, lower part) under conditions of summer stratification and during the gradual increase in mixing depth from December to February. See Fig. 2 and Table 1 for mixing depths

$750 \mu \mathrm{m}$ and retained by 400 and $100 \mu \mathrm{m}$ mesh, were homogeneously distributed in February, when the water column was deeply mixed, but not in September, when the water column was stratified (Fig. 4a,b, Tables 3 \& 4). Unlike all other small size organisms, the vertical distribution of tintinnids was also nearly homogeneous in the upper $200 \mathrm{~m}$ in September $\left(\mathrm{R}_{1}=1.2\right)$ but stratified when the full column was considered $\left(R_{2}=13\right.$; Fig. 4a). Both small and large $(>750 \mu \mathrm{m})$ chaetognaths exhibited a clear shift from strong stratification in the summer $\left(R_{1}=10 ; R_{2}=15\right)$ to homogeneity in the winter $\left(R_{1}, R_{2}=1.4\right)$. In contrast, large cope-

Table 2. One-way ANOVA and post-hoc test of $\mathrm{R}_{1}$, the ratio of zooplankton abundance between the 0-100 $\mathrm{m}$ and the 100-200 m layers, and $\mathrm{R}_{2}$, the ratio between the 0-200 m and the 200-400 m layers, in Summer (S), December (D), January $(\mathrm{J})$ and February $(\mathrm{F})$. The data was log-transformed in order to comply with the condition of homogeneity of variance (Cochran's test, $p>0.05$ ). Headings in the columns of the post-hoc test indicate the corresponding comparisons (e.g. SvsD indicates Summer versus December). ${ }^{* * *} \mathrm{p}<0.001,{ }^{* *} \mathrm{p}<0.01$, ${ }^{*} \mathrm{p}<0.05$, ns: not significant

\begin{tabular}{|lccccccccccc|}
\hline & \multicolumn{3}{c}{ One-Way ANOVA } & \multicolumn{4}{c|}{ Post-hoc test Tukey's HSD } \\
Source & df & MS & F-ratio & p & SvsD & SvsJ & SvsF & DvsJ & DvsF JvsF \\
\hline $\mathrm{R}_{1}$ & 3 & 0.487 & 18.50 & $* * *$ & $* *$ & $* * *$ & $* *$ & ns & ns & ns \\
Error & 11 & 0.026 & & & & & & & & \\
& & & & & & & & & & \\
$\mathrm{R}_{2}$ & 3 & 0.58 & 17.44 & $* * *$ & ns & ns & $* * *$ & ns & $* *$ & $*$ \\
Error & 11 & 0.033 & & & & & & & & & \\
\hline
\end{tabular}

pods $(>750 \mu \mathrm{m})$ exhibited a stratified pattern even under deep mixing, primarily due to their diurnal descent to below $300 \mathrm{~m}$ depth. Their $\mathrm{R}$ ratios were nearly constant in both seasons $\left(\mathrm{R}_{1}=2.6\right.$ and 2.1 , and $\mathrm{R}_{2}=0.5$ and 1.0, in September and February, respectively) (Fig. 4c, Tables 3 \& 4).

Pleuromamma indica adults and copepodites retained their diel vertical migration year round, even under the extreme mixing conditions in February 1992 while exhibiting greater homogeneity within the upper $200 \mathrm{~m}$ during the winter mixing (Fig. 5a,b). The copepodites exhibited a significant decrease (Mann-Whitney $U$-test, $\mathrm{p}<0.05$ ) in the nocturnal $\mathrm{R}_{1}$ from a summer average \pm SD of $24 \pm 26$ to $0.8 \pm 0.3$ from December to February (Fig. 5a). Similarly, $\mathrm{R}_{1}$ values for adults decreased from $8.8 \pm 8.5$ in summer to 1.1 in December and 0.8 in January (Fig. 5b). During all the sampling periods, some $30 \%$ of the adults seemed to avoid nocturnal ascent, remaining below $400 \mathrm{~m}$ at night (Fig. 5b).

Typically for the Gulf of Aqaba (Lindell \& Post 1995 A. Genin unpubl. data), the vertical distribution of chl a co-varied with the depth of the mixed layer. Representative summer and winter profiles are shown in Fig. 6, indicating the deep homogenous distribution during winter and the stratified structure, with a deepchlorophyll maximum around $80 \mathrm{~m}$ in summer.

\section{DISCUSSION}

Winter mixing reaching 400 to $800 \mathrm{~m}$ is extreme for a warm ocean, probably a phenomenon unique to marginal seas (Genin et al. 1995, Zohary et al. 1998). This mixing provided an opportunity to detect the downward spreading of zooplankton to aphotic layers on a spatial scale of hundreds of meters and a temporal scale of months. Except for the big copepod Pleuromamma indica, the vertical distribution of all other zooplankton we investigated was nearly homogeneous throughout the mixed layer. The gradual increase of mixing depth from 146 to $214 \mathrm{~m}$ in December to $>500 \mathrm{~m}$ in February was followed by a corresponding increase in the vertical range of zooplankton homogeneity. This homogeneity, reaching some $400 \mathrm{~m}$ below the photic layer in winter $\left(\mathrm{R}_{1}, \mathrm{R}_{2} \approx 1.0\right)$, sharply contrasted with the steep decline in zooplankton density below the photic layer when the water column was stratified $\left(\mathrm{R}_{1} 4\right.$ to 18 , $\mathrm{R}_{2} 5$ to 19). In other warm oligotrophic oceans where the water column is sta- 


\section{February 1992}

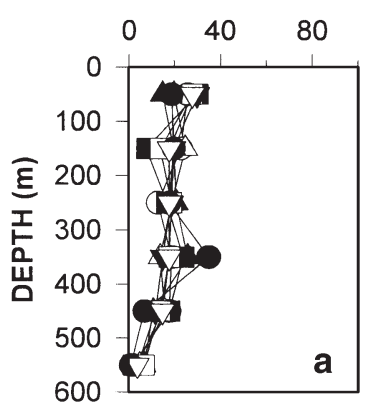

PERCENTAGE (\%)
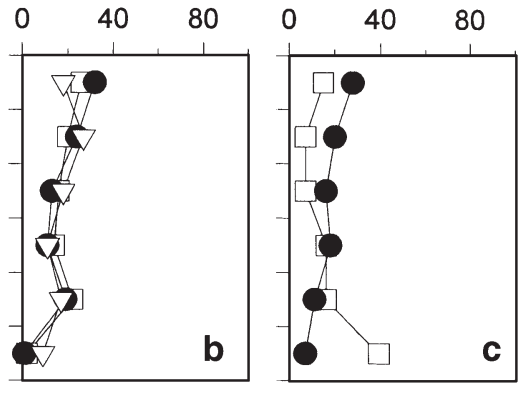

\section{September 1992}

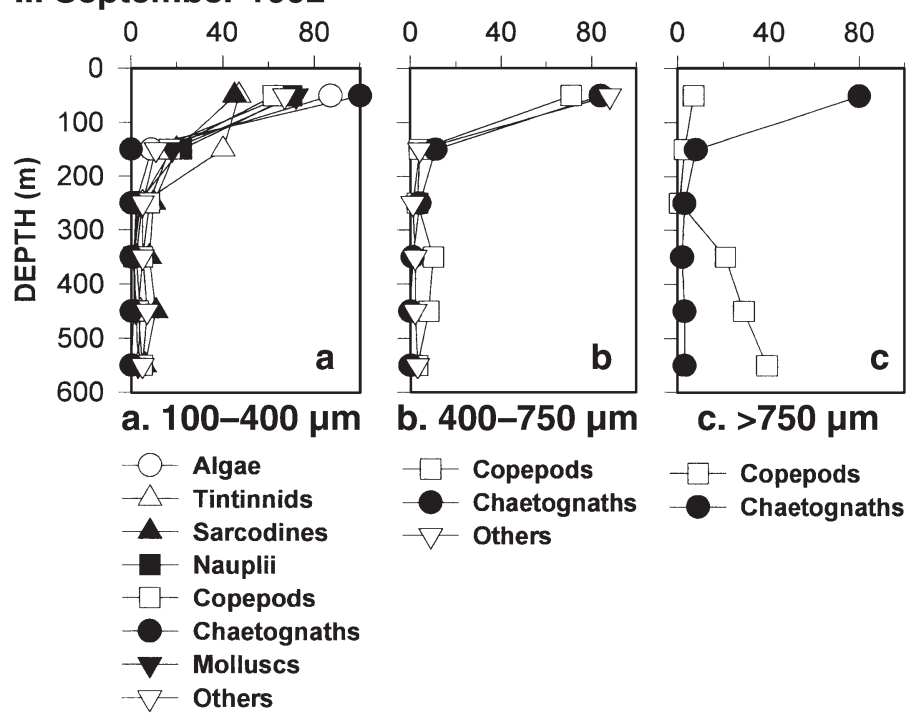

Fig. 4. Vertical profiles of size-fractionated zooplankton groups during the day in February 1992 when the mixed layer depth was $510 \mathrm{~m}$ (I, upper panels) and in September 1992, when the mixed layer was approx. $20 \mathrm{~m}$ deep (II, lower panels). (a) The group of smallest animals, passing through $400 \mu \mathrm{m}$ and retained on $100 \mu \mathrm{m}$ mesh; (b) the group of intermediate animals, passing through $750 \mu \mathrm{m}$ and retained on $400 \mu \mathrm{m}$ mesh; $_{\text {; }}$ (c) the group of largest animals, retained on $750 \mu \mathrm{m}$ mesh. Zooplankton abundance is presented as percentages in each $100 \mathrm{~m}$ thick layer of the total integrated over the $600 \mathrm{~m}$ water column. See Table 3 for the total number of animals in each group. Profiles with less than a total of 1500 ind. $\mathrm{m}^{-2}$ (integrated over the entire water column) were omitted from the analysis bly stratified, $\mathrm{R}_{1}$ ranges from 3.6 and higher yearround (Hopkins 1982, Böttger 1987, Schneider et al. 1994, Mazzocchi et al. 1997), with extreme values of 13 to 16 in the Red Sea (Weikert 1982, Beckmann 1984).

For logistical reasons, temperature profiles could not be obtained simultaneously with zooplankton profiles during this study. Nevertheless, simultaneous measurements of sea-surface temperature and mixed layer depth (Fig. 1, right panel) indicated that within a season the former variable was a reliable predictor of the latter. Thus, our error in inferring mixed layer depth based on a SST during the days of our zooplankton sampling unlikely exceeded $50 \mathrm{~m}$.

Our coarse sampling protocol (once a month) and lack of replication (single day and night profiles per cruise) weakened our conclusion regarding the correspondence between mixing and animal distribution. Nevertheless, the repetition of the same pattern during the 2 winters of our study strengthened that conclusion, as did the reports by Almeida Prado-Por (1983) and Böttger-Schnack et al. (2001) from our study site during 2 additional winters $(1975,1999)$. Almeida Prado-Por (1983) observed a fairly uniform vertical distribution of calanoid copepods between the surface and $500 \mathrm{~m}$ during winter 1975, while BöttgerSchnack et al. (2001) reported homogeneity of epipelagic cyclopoids throughout the upper $350 \mathrm{~m}$ in late winter 1999.

The effect of vertical mixing on the spreading and homogeneity of zooplankton distribution was reported from other oceans but on much smaller spatial and temporal scales (20 to $80 \mathrm{~m}$; a few days). Incze et al. (1990) reported such homogeneity for microzooplankton throughout the upper $70 \mathrm{~m}$ of the water column in the northwestern Gulf of Alaska, Haury et al. (1990) observed it for larvaceans in the upper $80 \mathrm{~m}$ in Monterey Bay, California, while Lagadeuc et al. (1997) reported such homogeneity throughout the

Table 3. Abundance (ind. $\mathrm{m}^{-2}$ ) of the size-fractionated groups integrated over the $600 \mathrm{~m}$ deep column in diurnal hauls in February 1992, when the mixed layer depth was $510 \mathrm{~m}$, and September 1992, when the mixed layer depth was around $20 \mathrm{~m}$

\begin{tabular}{|c|c|c|c|c|c|c|c|c|c|}
\hline Mesh size $(\mu \mathrm{m})$ & Month & Algae & Tintinnina & Sarcodina & Nauplii & Copepoda & Chaetognatha & Mollusca & Others \\
\hline \multirow[t]{2}{*}{$100-400$} & Feb & $2.2 \times 10^{5}$ & $7.0 \times 10^{4}$ & $1.5 \times 10^{4}$ & $1.0 \times 10^{5}$ & $5.7 \times 10^{5}$ & $2.9 \times 10^{3}$ & $3.8 \times 10^{4}$ & $1.1 \times 10^{5}$ \\
\hline & Sep & $3.6 \times 10^{4}$ & $3.4 \times 10^{4}$ & $2.3 \times 10^{4}$ & $1.1 \times 10^{5}$ & $5.7 \times 10^{5}$ & $2.5 \times 10^{3}$ & $7.9 \times 10^{4}$ & $1.1 \times 10^{5}$ \\
\hline \multirow[t]{2}{*}{$400-750$} & Feb & & & & & $4.6 \times 10^{4}$ & $5.7 \times 10^{3}$ & & $3.5 \times 10^{3}$ \\
\hline & Sep & & & & & $6.7 \times 10^{4}$ & $2.5 \times 10^{3}$ & & $8.2 \times 10^{3}$ \\
\hline \multirow[t]{2}{*}{$>750$} & Feb & & & & & $1.5 \times 10^{3}$ & $5.2 \times 10^{3}$ & & \\
\hline & Sep & & & & & $4.8 \times 10^{3}$ & $3.5 \times 10^{3}$ & & \\
\hline
\end{tabular}




\section{a. Copepodites}

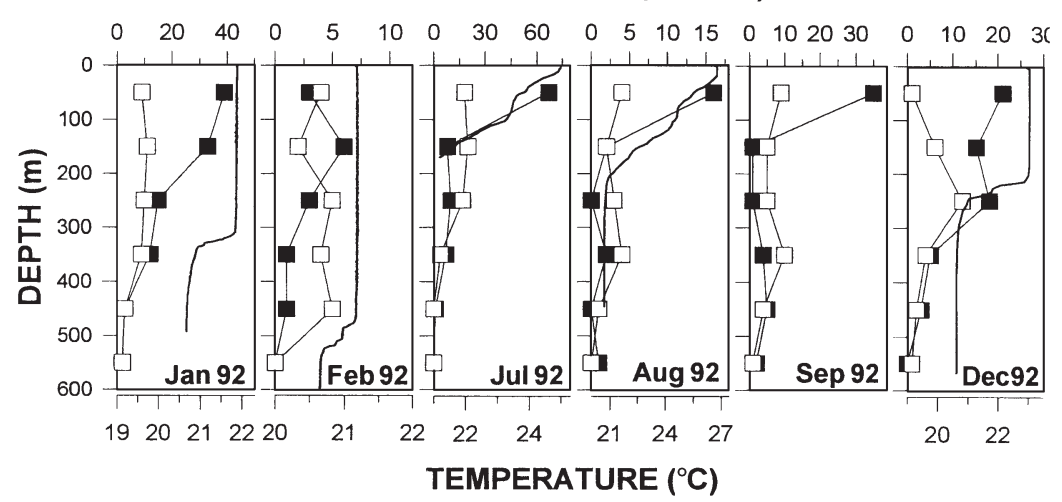

\section{b. Adults}

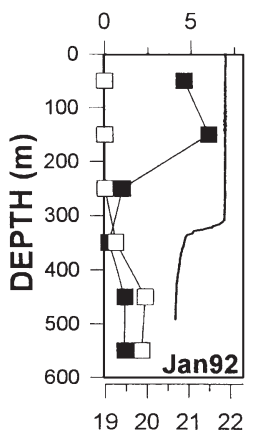

ABUNDANCE (no. $\mathrm{m}^{-3}$ )

\section{ABUNDANCE (no. $\mathrm{m}^{-3}$ )}

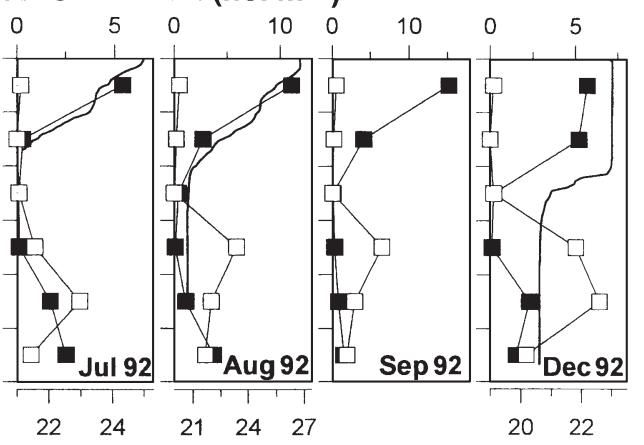

TEMPERATURE $\left({ }^{\circ} \mathrm{C}\right)$

Fig. 5. Pleuromamma indica. Diurnal ( $\square$ ) and nocturnal (घ) profiles of copepodites (a, upper panels) and adults (b, lower panels) and the corresponding temperature profiles (heavy lines) in 3 winter and 3 summer months in 1992. The plot of adults in February 1992 was omitted due to the scarcity of these animals $\left(\approx 300\right.$ ind. $\left.\mathrm{m}^{-2}\right)$

upper $20 \mathrm{~m}$ for copepod nauplii in the Baie des Chaleurs, Canada.

Spreading and homogeneity in the vertical distribution of phytoplankton in deeply mixed water columns were observed at our study site (Kimor \& Golandsky 1977 , Winter et al. 1979, Lindell \& Post 1995) as well as at many

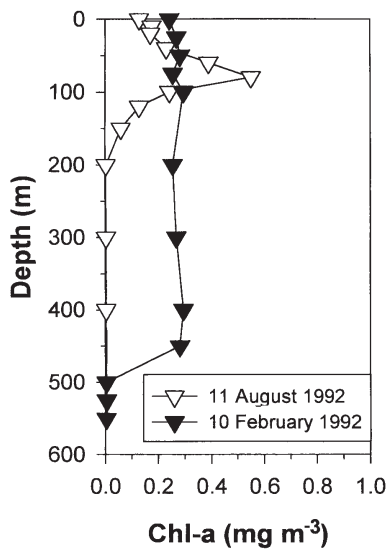

Fig. 6. Vertical profiles of chl a collected with niskin bottles at Stn A in winter (February) and in summer (August) 1992

other regions worldwide (Sverdrup 1953, Pingree et al. 1975, Bradford et al. 1982, Zohary et al. 1998). Deep mixing is obviously deleterious for phytoplankton, as the cells which are mixed down to aphotic layers (as much as $85 \%$ in the Gulf of Aqaba in February) cannot photosynthesize. For herbivorous zooplankton, however, the spreading to aphotic layers may not be similarly deleterious as their food (phytoplankton) is also spread throughout the mixed layer.

The changes from stratified distribution in the summer to vertical homogeneity in the winter were most distinctive for small zooplankters. Large chaetognaths (retained on $750 \mu \mathrm{m}$ mesh), which are found in the upper $100 \mathrm{~m}$ in the Gulf of Aqaba, displaying little, if any, diel vertical migration (Schmidt 1973), exhibited a change from stratified to homogeneous distribution identical to that of the smaller zooplankton (Fig. 4c). Conversely, large copepods (Fig. 4c) such as Pleuromamma indica (Fig. 5), a group likely consisting of many diel migrators (Brooks \& Mullin 1983, Bennett \&

Table 4. Ratios $\mathrm{R}_{1}$ and $\mathrm{R}_{2}$ for the size-fractionated groups in the diurnal hauls in February 1992, when the mixed layer depth was $510 \mathrm{~m}$, and September 1992, when the mixed layer depth was around $20 \mathrm{~m}$. -: $100 \%$ of the specimens were found in the upper $100 \mathrm{~m}$ of the water column

\begin{tabular}{|c|c|c|c|c|c|c|c|c|c|}
\hline $\begin{array}{l}\text { Mesh size } \\
(\mu \mathrm{m})\end{array}$ & Month & $\begin{array}{l}\text { Algae } \\
\mathrm{R}_{1} \quad \mathrm{R}_{2}\end{array}$ & $\begin{array}{l}\text { Tintinnina } \\
\mathrm{R}_{1} \quad \mathrm{R}_{2}\end{array}$ & $\begin{array}{l}\text { Sarcodina } \\
\mathrm{R}_{1} \quad \mathrm{R}_{2}\end{array}$ & $\begin{array}{c}\text { Nauplii } \\
\mathrm{R}_{1} \quad \mathrm{R}_{2}\end{array}$ & $\begin{array}{c}\text { Copepoda } \\
\mathrm{R}_{1} \mathrm{R}_{2}\end{array}$ & $\begin{array}{l}\text { Chaetognatha } \\
\qquad R_{1} \quad R_{2}\end{array}$ & $\begin{array}{c}\text { Mollusca } \\
\mathrm{R}_{1} \quad \mathrm{R}_{2}\end{array}$ & $\begin{array}{l}\text { Others } \\
\mathrm{R}_{1} \quad \mathrm{R}_{2}\end{array}$ \\
\hline $100-400$ & $\begin{array}{l}\text { Feb } \\
\text { Sep }\end{array}$ & $\begin{array}{ll}1.1 & 1.6 \\
9.7 & 44\end{array}$ & $\begin{array}{ll}0.8 & 1.3 \\
1.2 & 13\end{array}$ & $\begin{array}{ll}0.8 & 0.8 \\
2.3 & 3.6\end{array}$ & $\begin{array}{ll}3.5 & 0.9 \\
3.2 & 27\end{array}$ & $\begin{array}{ll}2.0 & 1.2 \\
3.7 & 6.1\end{array}$ & $\begin{array}{cc}0.9 & 0.8 \\
- & -\end{array}$ & $\begin{array}{ll}1.5 & 1.5 \\
4.0 & 18\end{array}$ & $\begin{array}{ll}1.5 & 1.3 \\
5.9 & 7.9\end{array}$ \\
\hline $400-750$ & $\begin{array}{l}\text { Feb } \\
\text { Sep }\end{array}$ & & & & & $\begin{array}{ll}1.3 & 1.5 \\
18 & 5.9\end{array}$ & $\begin{array}{ll}1.4 & 2.3 \\
7.5 & 19\end{array}$ & & $\begin{array}{rl}0.7 & 1.6 \\
24 & 33\end{array}$ \\
\hline$>750$ & $\begin{array}{l}\text { Feb } \\
\text { Sep }\end{array}$ & & & & & $\begin{array}{ll}2.1 & 1.0 \\
2.6 & 0.5\end{array}$ & $\begin{array}{rl}1.4 & 1.4 \\
10 & 15\end{array}$ & & \\
\hline
\end{tabular}


Hopkins 1989), retained their diel migration pattern even when the water column was deeply mixed. The only apparent change in the vertical migration of $P$. indica was a sharp decrease in their nocturnal $\mathrm{R}_{1}$. That is, while under stratified conditions these copepods ascended at night to the upper $100 \mathrm{~m}$ (= the photic zone), under deep mixing conditions their distribution was homogeneous throughout the upper $200 \mathrm{~m}$ of the mixed layer $\left(R_{1}=0.8 \pm 0.3\right.$ for copepodites $)$. This nocturnal pattern was likely a result of the homogeneity of their food. In adjacent waters in the Red Sea south of the Gulf, where the water column is stratified year round, most $(95 \pm 10 \%)$ of $P$. indica ascend daily to the upper $100 \mathrm{~m}$ (equivalent to $\mathrm{R}_{1} \approx 19$ ) even in the winter (March 1979, Beckmann 1984).

What is the mechanism that produces vertical extension and homogeneity in the distribution of zooplankton? Two, not mutually exclusive mechanisms, are likely: One is 'active', in which homogeneous distribution is reached by isotropic swimming of the zooplankton; the other is 'passive', in which similarly to phytoplankton, the animals are passively entrained by the mixing water. The active mechanism could be an optimal response as predicted by the model of Ideal Free Distribution (Fretwell \& Lucas 1970, Begon et al. 1990), as a homogeneous distribution of grazers throughout the volume in which their food is uniformly distributed would minimize competition for food. It might also be a reaction to vertical changes in the intensity of the ambient turbulence, as suggested by Mackas et al. (1993) for the copepods Neocalanus plumchrus and $N$. flemingeri in the subarctic Pacific. On the other hand, the passive mechanism should depend on the turbulence intensity, the vertical current shear, and the zooplankton ability to overcome vertical displacement. It is likely that under conditions of high turbulence and strong vertical current shear strong migrators (but not weak ones) will either be able to retain their vertical position or evade the mixed layer. These expectations are supported by the observations of Lagadeuc et al. (1997), showing that the distribution of nauplii but not adult copepods became homogeneous throughout a $20 \mathrm{~m}$ wind-mixed layer. Haury et al. (1990) demonstrated that weak swimmers such as shallow-living larvaceans and deep-living Oithona that were vertically separated under calm sea conditions became vertically mixed during a storm. Conversely, they found that the strong swimmer and migrator Metridia pacifica Copepodite stage $\mathrm{V}$ retained its position at the same depth. Also in our study, the large copepod Pleuromamma indica retained its diel migration behavior regardless of water mixing. Its migration consisted of a bi-daily swim of 300 to $500 \mathrm{~m}$, clearly indicating its good swimming ability. Euphausiids, which are good swimmers, by and large avoided the vertical net used in this study.
For qualitative examination of their vertical migration, in February 2000 (mixing depth $430 \mathrm{~m}$ ) a large Bongo net $(70 \mathrm{~cm}$ mouth diameter, $300 \mu \mathrm{m}$ mesh) was obliquely towed by 2 of us (V. Farstey \& A. Genin) at $150 \mathrm{~cm} \mathrm{~s}^{-1}$ from $100 \mathrm{~m}$ to the surface (bottom depth 600 to $700 \mathrm{~m}$ ). The Bongo net minimizes the avoidance problem, and is reliably used to sample euphausiids and similarly sized zooplankton (Brinton 1967). The nocturnal Bongo hauls caught large quantities $\left(>10\right.$ ind. $\mathrm{m}^{-3}$ ) of the krill Euphausia diomedeae Ortmann, 1894 (10 to $12 \mathrm{~mm}$ in length) and several other large decapods, none of which were present in that layer during the day. Evidently, large strong swimmers retained their diel vertical migration behavior in spite of mixing. The diel vertical migration is possibly a 'fixed' behavior, determined by proximal factors such as light, yet with a limited flexibility to 'fine tune' the nocturnal depth based on food availability (Huntley \& Brooks 1982, Daro 1988). Such a modulation of nocturnal range apparently caused the observed decrease (10 to 20 fold) of $P$. indica's $\mathrm{R}_{1}$ with the onset of deep mixing (Fig. 5).

In order to evaluate the extent of zooplankton homogeneity in the mixed layer, the observations were compared with the distribution expected for a passive tracer. A simple model used a 'sampling procedure' based on $100 \mathrm{~m}$ intervals identical to those used in the field. Thus the proportion of the 'population' of the passive tracer found in the upper $100 \mathrm{~m}$ (of the total found in the mixed layer only) was expected to follow a $X^{-1}$ curve, where $X$ is the number of full $100 \mathrm{~m}$ intervals in the mixed layer. Note that the depth of the mixed layer in this comparison was considered to be the number of $100 \mathrm{~m}$ intervals that were fully included in the actual mixed layer. For example, in a case of actual 316 m mixing (January 1992), 3 such intervals were included in the mixed layer, so that the expected proportion in the upper $100 \mathrm{~m}$ is $1 / 3$. The comparison of the expected and observed data (Fig. 7) indicated that the zooplankton followed the trend expected for a passive tracer, although the observed proportion near the surface was, on average, $11 \pm 6 \%$ higher. Accordingly, the exponent value of the power regression line was -0.8 , compared with the expected value of -1.0 $\left(\mathrm{R}^{2}=0.98\right.$; Fig. 7). The fraction of strong swimming zooplankton was too small (typically $<0.1 \%$ of the total; Table 3) to explain this difference from the model. A possible explanation is that the mixed layer consisted of 2 parts. An upper part, comprising most of the mixed layer, in which mixing was more intense and the distribution of organisms was homogeneous, and a lower part, adjacent to the deepening thermocline, in which the mixing was weaker allowing gradients. The first evidence for this pattern is based on the results: the density of zooplankton in the bottom $100 \mathrm{~m}$ of the 


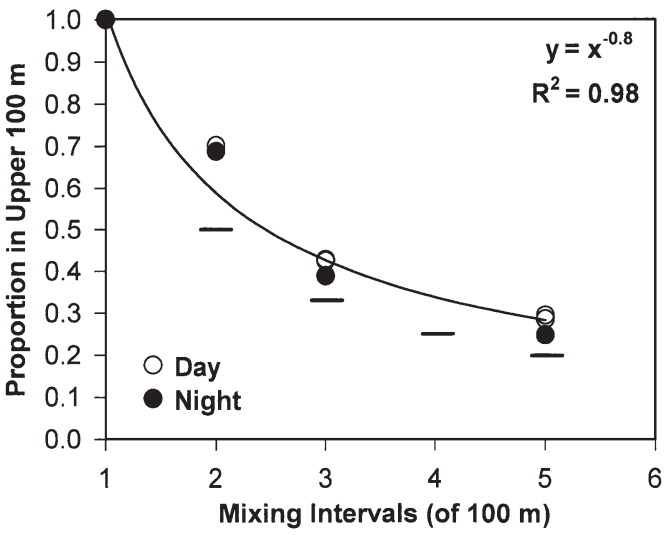

Fig. 7. Comparison between the observed and expected proportion of zooplankton in the upper $100 \mathrm{~m}$ under different depths of vertical mixing. See text for a description of the model. Circles: observed data; horizontal bars: predicted values. The observed data power regression line and its parameters are indicated on the top right

mixed layer (i.e. the 100 to $200 \mathrm{~m}$ layer in December 1992, the 200 to $300 \mathrm{~m}$ layer in January, and the 400 to 500 m layer in February 1992) was consistently lower than the density in shallower parts of the corresponding mixed layer (see Fig. 2). On average, in this lower section of the mixed layer the zooplankton density was $47 \pm 13 \%$ lower than in the almost perfectly homogeneous layer above (Fig. 2a,b). The second evidence is based on a similar trend observed for phytoplankton: vertical profiles of in vivo fluorescence measured by B. Lazar (unpublished data from November 1999 through December 2001; maximum mixing depth of $640 \mathrm{~m}$ in February) showed uniform fluorescence in the top part but a decline in the lower part (10s of meters). These 2 biological trends possibly indicated the occurrence of weaker mixing near the thermocline, allowing zooplankton to resist downward entrainment in that layer (and causing phytoplankton to remain in darkness long enough to change their in vivo fluorescence). Thus, it is likely that strong convective mixing in the winter causes zooplankton to spread throughout the mixed layer. However, zooplankton attains a full homogeneity comparable to that of a passive tracer only in the upper section of the mixed layer.

How should vertical expansion and homogeneity of zooplankton affect the community? First, as mentioned above, it should minimize competition for food among herbivorous zooplankters. Second, a dramatic decline in the absolute zooplankton density was observed in the upper $100 \mathrm{~m}$ as mixing deepened, reaching a $\times 5$ dilution by February (Fig. 2a). This dilution could significantly lower zooplankton predation by visual predators in the upper, illuminated portion of the water column due to the linear functional response of zooplanktivorous fish (Gerking 1994). However, this reduced predation could have been offset by a parallel increase in the zooplankton density in the deeper layers, although predation is much reduced at aphotic layers. No clear trend was apparent in the integrated zooplankton abundance throughout the water column between mixed and stratified conditions. Zooplankton predators residing in the upper layer, which rely on high prey density for their growth and survival, may severely suffer from the reduced prey density during mixing (Lasker 1975, Buckley \& Lough 1987). On the other hand, deep-water predators, as well as the deepsea bottom community, should benefit from the higher densities of prey during the mixing period and the shorter time it takes sinking particles to reach great depths. To the best of our knowledge, this is the first description of such a remarkable extension and homogeneity of zooplankton distribution driven by deep convective mixing. These findings may have relevance for other areas where such deep winter mixings occur.

Acknowledgements. We thank A. Baranes and the staff of the H. Steinitz Marine Biology Laboratory of the Interuniversity Institute of Eilat for logistic help and for supporting our cruises. We thank D. Ben-Ezra for help with fieldwork and the captains S. Mashiach and Z. Prital and the crew of RV 'Jadran' for their professional work at sea. We are grateful to F. D. Por and M. S. Almeida Prado-Por for their help and encouragement; they, L. Haury and D. Lindell provided helpful comments on the manuscript. Thanks to P. Kitaeff for help with English editing. This research was sponsored by grants from the Ecological Foundation of the Keren Kayemet Le-Israel and the Israel Science Foundation. This contribution is a partial result of a $\mathrm{PhD}$ thesis by the first author.

\section{LITERATURE CITED}

Almeida Prado-Por MS (1983) The diversity and dynamics of Calanoida (Copepoda) in the Northern Gulf of Elat (Aqaba), Red Sea. Oceanol Acta 6:139-145

Beckmann W (1984) Mesozooplankton distribution on a transect from the Gulf of Aden to the central Red Sea during the winter monsoon. Oceanol Acta 7:87-102

Begon M, Harper JL, Townsend CR (1990) Ecology-individuals, populations and communities. Blackwell, Oxford

Bennett JL, Hopkins TL (1989) Aspects of the ecology of the calanoid copepod genus Pleuromamma in the eastern Gulf of Mexico. Contrib Mar Sci 31:119-136

Böttger R (1987) The vertical distribution of micro- and small mesozooplankton in the Central Red Sea. Biol Oceanogr 4: 383-402

Böttger-Schnack R, Hagen W, Schnack-Schiel SB (2001) The microcopepod fauna in the Gulf of Aqaba, northern Red Sea: species diversity and distribution of Oncaeidae (Poecilostomatoida). J Plankton Res 23:1029-1035

Bradford JM, Heath RA, Chang FH, Hay CH (1982) The effect of warm-core eddies on oceanic productivity off northeastern New Zealand. Deep-Sea Res Part A 29:1501-1516

Brinton E (1967) Vertical migration and avoidance capability of euphausiids in the California Current. Limnol Oceanogr 12:451-483 
Brooks ER, Mullin MM (1983) Diel changes in the vertical distribution of biomass and species in the Southern California Bight. Calif Coop Ocean Fish Invest Data Rep 24:210-215

Buckley LJ, Lough RG (1987) Recent growth, biochemical composition, and prey field of larval haddock (Melanogrammus aeglefinus) and Atlantic cod (Gadus morhua) on Georges Bank. Can J Fish Aquat Sci 44:14-25

Checkley DM Jr, Uye S, Dagg MJ, Mullin MM, Omori M, Onbé T, Zhu MY (1992) Diel variation of the zooplankton and its environment at neritic stations in the Inland Sea of Japan and the north-west Gulf of Mexico. J Plankton Res 14:1-40

Daro MH (1988) Migratory and grazing behavior of copepods and vertical distribution of phytoplankton. Bull Mar Sci 43: 710-729

Fretwell SD, Lucas HL (1970) On territorial behaviour and other factors influencing habitat distribution in birds. Acta Biotheor 19:16-36

Genin A, Lazar B, Brenner S (1995) Vertical mixing and coral death in the Red Sea following the eruption of Mount Pinatubo. Nature 377:507-510

Gerking SD (1994) Feeding ecology of fish. Academic Press, San Diego

Haury LR, Yamazaki H, Itsweire EC (1990) Effects of turbulent shear flow on zooplankton distribution. Deep-Sea Res Part A 37:447-461

Hopkins TL (1982) The distribution of zooplankton in the eastern Gulf of Mexico. Deep-Sea Res Part A 29:1069-1083

Huntley M, Brooks ER (1982) Effects of age and food availability on diel vertical migration of Calanus pacificus. Mar Biol 71:23-31

Incze LS, Ortner PB, Schumacher JD (1990) Microzooplankton, vertical mixing and advection in a larval fish patch. J Plankton Res 12:365-379

Incze LS, Aas P, Ainaire T (1996) Distributions of copepod nauplii and turbulence on the southern flank of Georges Bank: implications for feeding by larval cod (Gadus morhua). Deep-Sea Res II 43:1855-1873

Kimor B, Golandsky B (1977) Microplankton of the Gulf of Elat: aspects of seasonal and bathymetric distribution. Mar Biol 42:55-67

Lagadeuc Y, Boulé M, Dodson JJ (1997) Effect of vertical mixing on the vertical distribution of copepods in coastal waters. J Plankton Res 19:1183-1204

Lasker R (1975) Field criteria for survival of anchovy larvae: The relation between inshore chlorophyll maximum layers and successful first feeding. Fish Bull 71:453-462

Lindell D, Post AF (1995) Ultraphytoplankton succession is triggered by deep winter mixing in the Gulf of Aqaba (Eilat), Red Sea. Limnol Oceanogr 40:1130-1141

Editorial responsibility: Kenneth Sherman (Contributing Editor), Narragansett, Rhode Island, USA
Longhurst AR (1998) Ecological geography of the sea. Academic Press, San Diego

Mackas DL, Sefton H, Miller CB, Raich A (1993) Vertical habitat partitioning by large calanoid copepods in the oceanic subarctic Pacific during spring. Prog Oceanogr 32: 259-294

Mazzocchi MG, Christou ED, Fragopoulu N, Siokou-Frangou I (1997) Mesozooplankton distribution from Sicily to Cyprus (Eastern Mediterranean): I. General aspects. Oceanol Acta 20:521-535

Menzel DW, Ryther JH (1960) The annual cycle of primary production in the Sargasso Sea off Bermuda. Deep-Sea Res 6:351-367

Pingree RD, Pugh PR, Holligan PM, Forster GR (1975) Summer phytoplankton blooms and red tides along tidal fronts in the approaches to the English Channel. Nature 258: 672-677

Reiss Z, Hottinger L (1984) The Gulf of Aqaba. Ecological micropalaeontology. Springer-Verlag, Berlin

Schmidt HE (1973) The vertical distribution and diurnal migration of some zooplankton in the Bay of Eilat (Red Sea). Helgol Wiss Meeresunters 24:333-340

Schneider G, Lenz L, Rolke M (1994) Zooplankton standing stock and community size structure within the epipelagic zone: a comparison between the central Red Sea and the Gulf of Aden. Mar Biol 119:191-198

Simó R, Pedrós-Alió C (1999) Role of vertical mixing in controlling the oceanic production of dimethyl sulphide. Nature 402:396-399

Sverdrup HU (1953) On conditions for the vernal blooming of phytoplankton. J Cons Int Explor Mer 18:287-295

Tranter DJ, Parker RR, Cresswell GR (1980) Are warm-core eddies unproductive? Nature 284:540-542

Weikert H (1982) The vertical distribution of zooplankton in relation to habitat zones in the area of the Atlantis II Deep, Central Red Sea. Mar Ecol Prog Ser 8:129-143

Williams R (1985) Vertical distribution of Calanus finmarchicus and C. helgolandicus in relation to the development of the seasonal thermocline in the Celtic Sea. Mar Biol 86: $145-149$

Winter A, Reiss Z, Luz B (1979) Distribution of living coccolithophore assemblages in the Gulf of Elat (Aqaba). Mar Micropaleontol 4:197-223

Wolf-Vecht A, Paldor N, Brenner S (1992) Hydrographic indications of advection/convection effects in the Gulf of Elat. Deep-Sea Res Part A 39:1393-1401

Zohary T, Brenner S, Krom MD, Angel DL, Kress N, Li WKW, Neori A, Yacobi YZ (1998) Buildup of microbial biomass during deep winter mixing in a Mediterranean warm-core eddy. Mar Ecol Prog Ser 167:47-57

Submitted: February 21, 2002; Accepted: April 19, 2002

Proofs received from author(s): July 23, 2002 